\title{
PERBANDINGAN AKTIVITAS SITOTOKSIK EKSTRAK DAN MINYAK ATSIRI RIMPANG Curcuma mangga Val. TERHADAP SEL MCF-7
}

\author{
(THE COMPARISON BETWEEN THE ACTIVITIES OF CYTOTOXIC EXTRACTS \\ AND ESSENTIAL OILS OF RHIZOME Curcuma mango Val. TOWARD MCF-7 CELLS)
}

\author{
Putri Khaerani Cahyaningrum, Purwanto, dan Retno S. Sudibyo \\ Fakultas Farmasi Universitas Gadjah Mada \\ Jl. Sekip Utara Yogyakarta, Indonesia - 55281 \\ email: Purwanto_fa@ugm.ac.id
}

\begin{abstract}
Abstrak
Rimpang Curcuma mangga Val. banyak digunakan sebagai obat herbal antikanker payudara. Penelitian aktivitas sitotoksik terhadap sel kanker payudara banyak dilakukan utamanya untuk minyak atsiri rimpang, dan hanya sedikit penelitian terhadap ekstraknya. Walaupun demikian belum ada yang membandingkan aktivitas sitotoksik dari ekstrak dan minyak atsiri tersebut terhadap sel kanker payudara; meskipun kandungan senyawa keduanya berbeda. Oleh karena itu penelitian ini bertujuan membandingkan aktivitas sitotoksik dari ekstrak dan minyak atsiri rimpang C. mangga Val. secara in vitro terhadap sel kanker payudara MCF7. Ekstrak rimpang dibuat secara maserasi menggunakan pelarut $n$-heksana; sedangkan minyak atsiri dibuat melalui destilasi uap irisan rimpang selama 5 jam. Uji aktivitas sitotoksik in vitro dilakukan menggunakan metoda MTT Assay. Rendemen minyak dari ekstrak $n$-heksana rimpang $C$. mangga Val. adalah $1,15 \times 10^{-2} \%$ sedangkan rendemen minyak atsiri adalah $6,3 \times 10^{-2} \%$. Hasil uji sitotoksik menghasilkan $\mathrm{IC}_{50}$ ekstrak $106,414 \mu \mathrm{g} / \mathrm{ml}\left(\mathrm{R}^{2}=0,9677\right)$ dan minyak atsiri $198,557 \mu \mathrm{g} / \mathrm{ml}\left(\mathrm{R}^{2}=0,8037\right)$. Hal ini menunjukkan bahwa ekstrak rimpang C. mangga Val. lebih sitotoksik terhadap sel kanker payudara MCF-7 daripada minyak atsirinya, karena kandungan ekstrak mayoritas diterpenoid $(53,18 \%)$ sedangkan minyak atsiri mayoritas monoterpenoid $(51,34 \%)$.

Kata kunci: Curcuma mangga Val., sel MCF7, aktivitas sitotoksik, minyak atsiri, ekstrak n-heksana
\end{abstract}

\begin{abstract}
Curcuma mangga Val. rhizome has been used as herbal anti breast cancer. Researches on cytotoxic activity towards breast cancer cells have been done especially to the rhizome's essential oil; and only few researches done to the extract. However there is no cytotoxic activity comparation of the extract and essential oil towards breast cancer cells; even tough their substance contents are different. Therefore, this study aimed to compare the cytotoxic activity in vitro of the extract and essential oil of $C$. mangga Val. rhizomes towards breast cancer cells of MCF-7. The rhizome extract was prepared by maceration using N-hexane; while the essential oil was prepared by steam distillation for 5 hours of the sliced rhizomes. The in vitro cytotoxic test was carried out using MTT Assay. The yield of oil from rhizome extract was $1.15 \times 10^{-2} \%$; while the yield of essential oil was $6.3 \times 10^{-2} \%$. The $\mathrm{IC}_{50}$ of extract oil was $106.414 \mu \mathrm{g} / \mathrm{ml}\left(\mathrm{R}^{2}=0.9677\right)$ and the $\mathrm{IC}_{50}$ of essential oil was $198.557 \mu \mathrm{g} / \mathrm{ml}\left(\mathrm{R}^{2}=0.8037\right)$. It shows that rhizome extract of $C$. mangga Val. was more cytotoxic towards MCF-7 than the oil because the majority content of extract were diterpenoids (53.18\%) while the oil were monoterpenoids (51.34\%).

Keywords: Curcuma mangga Val., MCF-7 cell line, cytotoxic activity, essential oil, n-hexane extract
\end{abstract}




\section{PENDAHULUAN}

Rimpang Curcuma mangga Val. banyak digunakan sebagai obat herbal antikanker payudara oleh masyarakat di sekitar Yogyakarta. Penelitian aktivitas sitotoksik terhadap sel kanker payudara telah dilakukan dari berbagai macam ekstrak dan fraksi rimpang Curcuma mangga Val. (Astuti, 2015; Malek et al., 2011; Sudibyo \& Taryono, 2020; Verlianara, 2004; Wahyuningsih dkk., 2003). Pada penelitian Malek (2011), ekstrak $n$-heksana memberikan nilai $\mathrm{IC}_{50}$ paling kecil $(8,1 \pm 0,2 \mu \mathrm{g} / \mathrm{ml})$ dibandingkan ekstrak metanol $(27,9 \pm 0,3 \mu \mathrm{g} / \mathrm{ml})$ maupun etil asetat $(47,1 \pm 0,5 \mu \mathrm{g} / \mathrm{ml})$ terhadap sel MCF-7. Uji sitotoksisitas ekstrak $n$-heksana terhadap sel T47D memberikan nilai $\mathrm{IC}_{50}$ beragam antara $15,875-106,772 \mu \mathrm{g} / \mathrm{ml}$ (Sudibyo \& Taryono, 2020).

Selain ekstrak, minyak atsiri rimpang C. mangga Val. telah diujikan pula terhadap berbagai sel kanker seperti sel raji, myeloma, HeLa, SiHa, dan T47D (Astuti dkk., 2014b; Verlianara, 2004). Verlianara (2004) menyebutkan bahwa minyak atsiri C. mangga Val. menginduksi apoptosis pada sel myeloma namun tidak pada sel Raji. Sedangkan Astuti (2015) menunjukkan potensi minyak atsiri rimpang C. mangga Val. sangat tinggi terhadap berbagai sel; SiHa 2,01 $\pm 0,1 \mu \mathrm{g} / \mathrm{ml}$, Myeloma 1,62 $\pm 0,14$

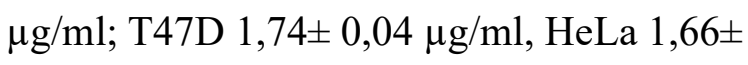
$0,07 \mu \mathrm{g} / \mathrm{ml}$ dan Raji 1,51 $\pm 0,05 \mu \mathrm{g} / \mathrm{ml}$.
Walaupun banyak penelitian telah melaporkan beragam potensi ekstrak dan minyak atsiri rimpang C. mangga Val., akan tetapi belum ada yang membandingkan aktivitas sitotoksik dari ekstrak dan minyak atsirinya terhadap sel kanker payudara; meskipun kandungan senyawa keduanya berbeda. Oleh karena itu, penelitian ini membandingkan senyawa kandungan dan aktivitas sitotoksik dari ekstrak dan minyak atsiri rimpang C. mangga Val. secara in vitro terhadap sel kanker payudara MCF7.

\section{METODE}

Bahan untuk pembuatan ekstrak dan minyak atsiri adalah rimpang Curcuma mangga Val. yang didapat dari Kecamatan Dlingo, Kabupaten Bantul, Yogyakarta. Bahan uji sitotoksik adalah sel kanker payudara MCF-7 dari koleksi laboratorium Parasitologi Fakultas Kedokteran UGM; media Dulbeco Modified Eagle Medium (DMEM) (Gibco), fetal bovine serum (FBS) (Gibco), penisilin-streptomisin, dan $1 \mathrm{mg} / \mathrm{ml}$ larutan 3-(4,5-Dimethylthiazol2-yl)-2,5,diphenyltetrazolium bromide) (MTT).

Rimpang C. mangga Val. disiapkan dengan diiris tipis lalu dikeringkan pada suhu $30^{\circ} \mathrm{C}$ selama 5 hari hingga didapatkan simplisia kering untuk pembuatan ekstrak dan minyak atsiri. Ekstrak n-heksana dibuat dengan metode maserasi dengan 
perbandingan simplisia:pelarut (1:3) selama 3 hari, diikuti dengan remaserasi selama 2 hari. Maserat diuapkan dalam vacuum rotary evaporator hingga didapatkan ekstrak kental. Sedangkan minyak atsiri didapatkan dari destilasi uap air $1 \mathrm{~kg}$ simplisia kering selama 5 jam. Minyak atsiri dikeringkan dari tapak-tapak air menggunakan natrium sulfat anhidrat. Ekstrak n-heksana dan minyak atsiri disimpan pada suhu $-20^{\circ} \mathrm{C}$.

Pembuatan seri konsentrasi ekstrak $n$-heksana dan minyak atsiri rimpang $\mathrm{C}$. mangga Val. dilakukan dengan melarutkan $10 \mathrm{mg}$ sampel ke dalam $1 \mathrm{ml}$ media kultur yang mengandung $0,1 \%$ DMSO. Konsentrasi seri kadar ekstrak dan sampel adalah 7,813; 15,$625 ; 31,25 ; 62,5 ; 125 ; 250$; dan $500 \mu \mathrm{g} /$ $\mathrm{ml}$.

Untuk uji sitotoksik, sel MCF-7 ditumbuhkan dalam media kultur DMEM dengan penambahan $10 \%$ FBS dan $1 \%$ penisilin-streptomisin dan diinkubasi pada inkubator $\mathrm{CO}_{2}$ dengan suhu $37^{\circ} \mathrm{C}$ selama 24 jam. Sejumlah $10^{4}$ sel dipindahkan ke dalam masing-masing sumuran dari 96well plate lalu diinkubasi kembali selama 24 jam. Sel kemudian diberi perlakuan seri kadar ekstrak dan minyak atsiri lalu diinkubasi selama 24 jam pada suhu $37^{\circ} \mathrm{C}$. Selanjutnya, setiap sumuran diberi $100 \mu 1$ larutan MTT ( $1 \mathrm{mg} / \mathrm{ml}$ dalam DMEM) dan diinkubasi selama 4 jam pada suhu $37^{\circ} \mathrm{C}$. Larutan MTT dibuang setelah terbentuk kristal formazan, lalu diberi $100 \mu 1$ larutan stopper (SDS 10\%), dan plate dibungkus dengan aluminium foil dan diinkubasi pada suhu ruang selama satu malam. Absorbansi sel diukur menggunakan ELISA reader pada panjang gelombang $595 \mathrm{~nm}$. Penentuan $\mathrm{IC}_{50}$ dilakukan menggunakan kurva regresi persentase viabilitas sel terhadap log konsentrasi sampel.

Fraksinasi dan identifikasi senyawa dalam ekstrak $n$-heksana dan minyak atsiri rimpang C. mangga Val. dilakukan dengan GC-MS (Thermoscientific Trace 1310 - MS ISQ LT) menggunakan kolom HP-5MS UI (panjang $30 \mathrm{~m}$; diameter 0,25 $\mathrm{mm}$; ketebalan film $0,25 \mu \mathrm{m}$; dan temperatur maksimum $325 / 350^{\circ} \mathrm{C}$ ). Gas pembawa yang digunakan adalah gas Helium UHP (He) dengan kecepatan alir $50 \mathrm{ml} / \mathrm{menit}$. Suhu injektor dan detektor berturut-turut adalah $260^{\circ} \mathrm{C}$ dan $250^{\circ} \mathrm{C}$; larutan uji diinjeksikan sebanyak $200 \mu 1$. Senyawa diidentifikasi berdasarkan waktu retensi, nama senyawa, struktur senyawa, berat molekul, similarity index (SI), dan kelimpahan relatif (\%). Ditentukan senyawa dan derivat senyawa dengan kelimpahan relatif terbanyak dalam ekstrak dan minyak atsiri C. mangga Val.

\section{HASIL PENELITIAN DAN PEMBAHASAN}

Rimpang C. mangga Val. dan hasil pembuatan ekstrak dan minyak atsiri rimpang C. mangga Val. terlihat pada 
Gambar 1. Dari ekstrak $n$-heksana yang didapat, setelah dilakukan sentrifugasi pada kecepatan 13.500 rpm selama 10 menit, didapatkan 2 lapisan lemak di bagian atas dan minyak di bagian bawah. Bagian minyak dari ekstrak $n$-heksana digunakan dalam uji sitotoksisitas (Gambar 1B). Hasil destilasi didapatkan minyak atsiri berwarna kuning pucat (Gambar 1C). Adapun rendemen dari ekstrak dan minyak atsiri rimpang $C$. mangga Val. tercantum dalam Tabel 1.

Hasil uji sitotoksik ekstrak $n$-heksana dan minyak atsiri rimpang C. mangga Val. terhadap sel MCF-7 terdapat pada Gambar
2 A dan B; sedangkan kurva regresi antara persentase viabilitas sel MCF-7 terhadap log konsentrasi minyak ekstrak $n$-heksana dan minyak atsiri rimpang C. mangga Val. terdapat pada Gambar 3 dan 4.

Gambar 3 dan 4 menunjukkan bahwa hubungan antara viabilitas sel MCF7 dan perubahan konsentrasi minyak ekstrak $n$-heksana lebih kuat $\left(\mathrm{R}^{2}=0,9677\right)$ daripada perubahan konsentrasi minyak atsiri $\quad\left(\mathrm{R}^{2}=0,8037\right)$, sedangkan potensi sitotoksisitas minyak ekstrak $n$-heksana juga lebih kuat $\left(\mathrm{IC}_{50}=106,41 \mu \mathrm{g} / \mathrm{ml}\right)($ Gambar 3) daripada minyak atsiri $\left(\mathrm{IC}_{50}=198,56 \mu \mathrm{g} /\right.$

\section{Gambar 1}

Irisan Rimpang C. mangga Val. (A), Ekstrak n-heksana (B), Minyak Atsiri (C)

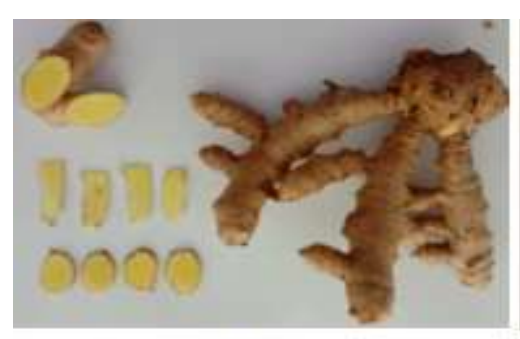

A

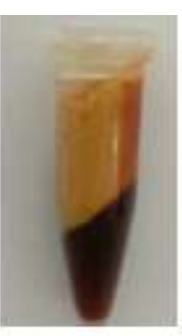

B

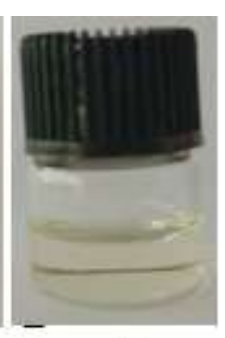

C

Tabel 1

Rendemen Ekstrak dan Minyak Atsiri Rimpang C. Mangga Val.

\begin{tabular}{clcc}
\hline No & \multicolumn{1}{c}{ Bahan/Rendemen } & Ekstrak & Minyak Atsiri \\
\hline 1 & Simplisia Segar & $1.900 \mathrm{~g}$ & $6.000 \mathrm{~g}$ \\
2 & Simplisia Kering & $300 \mathrm{~g}$ & $1.000 \mathrm{~g}$ \\
3 & Bobot ekstrak & $2,2 \times 10^{-1} \mathrm{~g}$ & - \\
4 & Bobot lemak & $3,155 \mathrm{~g}$ & - \\
5 & Bobot minyak atsiri & - & $3,791 \mathrm{~g}$ \\
6 & Rendemen terhadap rimpang segar & $1,15 \times 10^{-2} \%$ (fraksi minyak) & $6,3 \times 10^{-2} \%$ \\
& & $1,66 \times 10^{-1} \%$ (fraksi lemak) & \\
\hline
\end{tabular}


Perbandingan Aktivitas Sitotoksik (Cahyaningrum, P. K., Purwanto, \& Sudibyo, R. S.)

Gambar 2

Uji Sitotoksik (A), Minyak n-heksana (B), Minyak Atsiri Rimpang C. mangga Val. terhadap Sel MCF-7

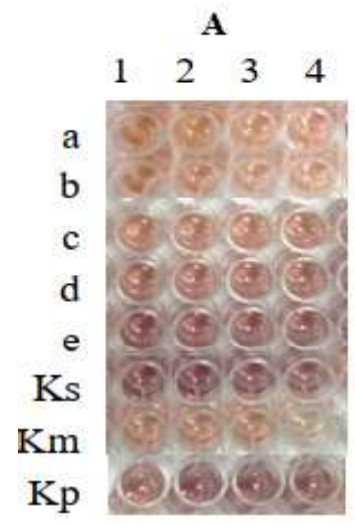

a. $31,25 \mu \mathrm{g} / \mathrm{ml}$, b. $62,5 \mu \mathrm{g} / \mathrm{ml}$, c. 125 $\mu \mathrm{g} / \mathrm{ml}$, d. $250 \mu \mathrm{g} / \mathrm{ml}$, e. $500 \mu \mathrm{g} / \mathrm{ml}, \mathrm{Ks}=$ Kontrol sel, $\mathrm{Km}=$ kontrol media, $\mathrm{Kp}=$ Kontrol pelarut

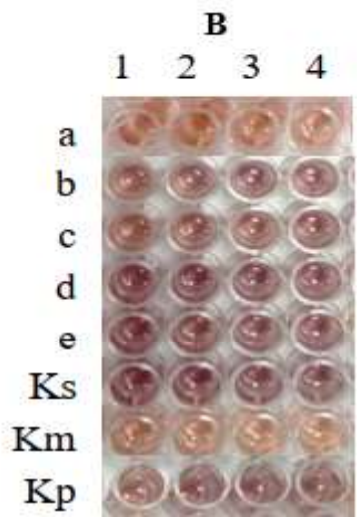

a. $15,625 \mu \mathrm{g} / \mathrm{ml}$, b. $31,25 \mu \mathrm{g} / \mathrm{ml}$, c. $62,5 \mu \mathrm{g} / \mathrm{ml}, \mathrm{d} .125 \mu \mathrm{g} / \mathrm{ml}$, e. $250 \mu \mathrm{g} /$ $\mathrm{ml}, \mathrm{Ks}=$ Kontrol sel, $\mathrm{Km}=$ kontrol media, $\mathrm{Kp}=$ Kontrol pelarut

Gambar 3

Kurva Sitotoksik Minyak dari Ekstrak C. mangga Val. terhadap Sel MCF-7 dengan Replikasi 3 kali, $R^{2}=0,9677$ dan $I C_{50} 106,41 \mu \mathrm{g} / \mathrm{ml}$

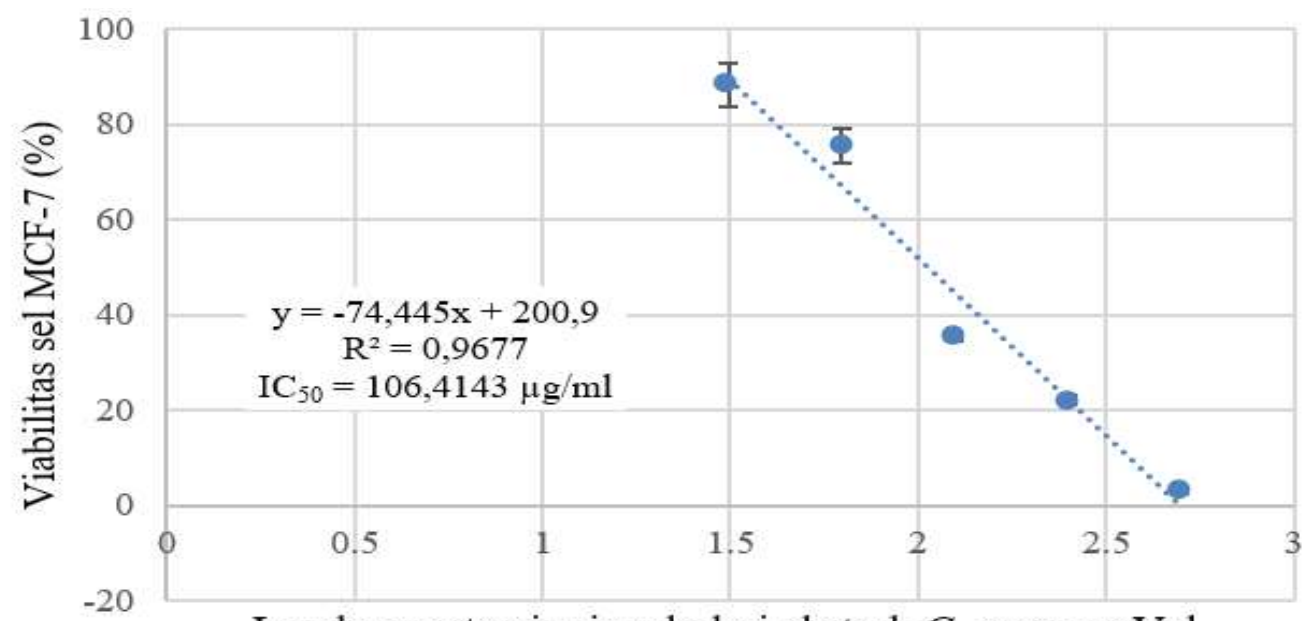

Log konsentrasi minyak dari ekstrak C. mangga Val. $(\mu \mathrm{g} / \mathrm{ml})$

ml) (Gambar 4). Kedua potensi sitotoksisitas di atas masuk dalam golongan cukup kuat menurut National Cancer Institute (NCI) karena $\mathrm{IC}_{50}>100 \mu \mathrm{g} / \mathrm{ml}$ (Boyd MR, 2004). 


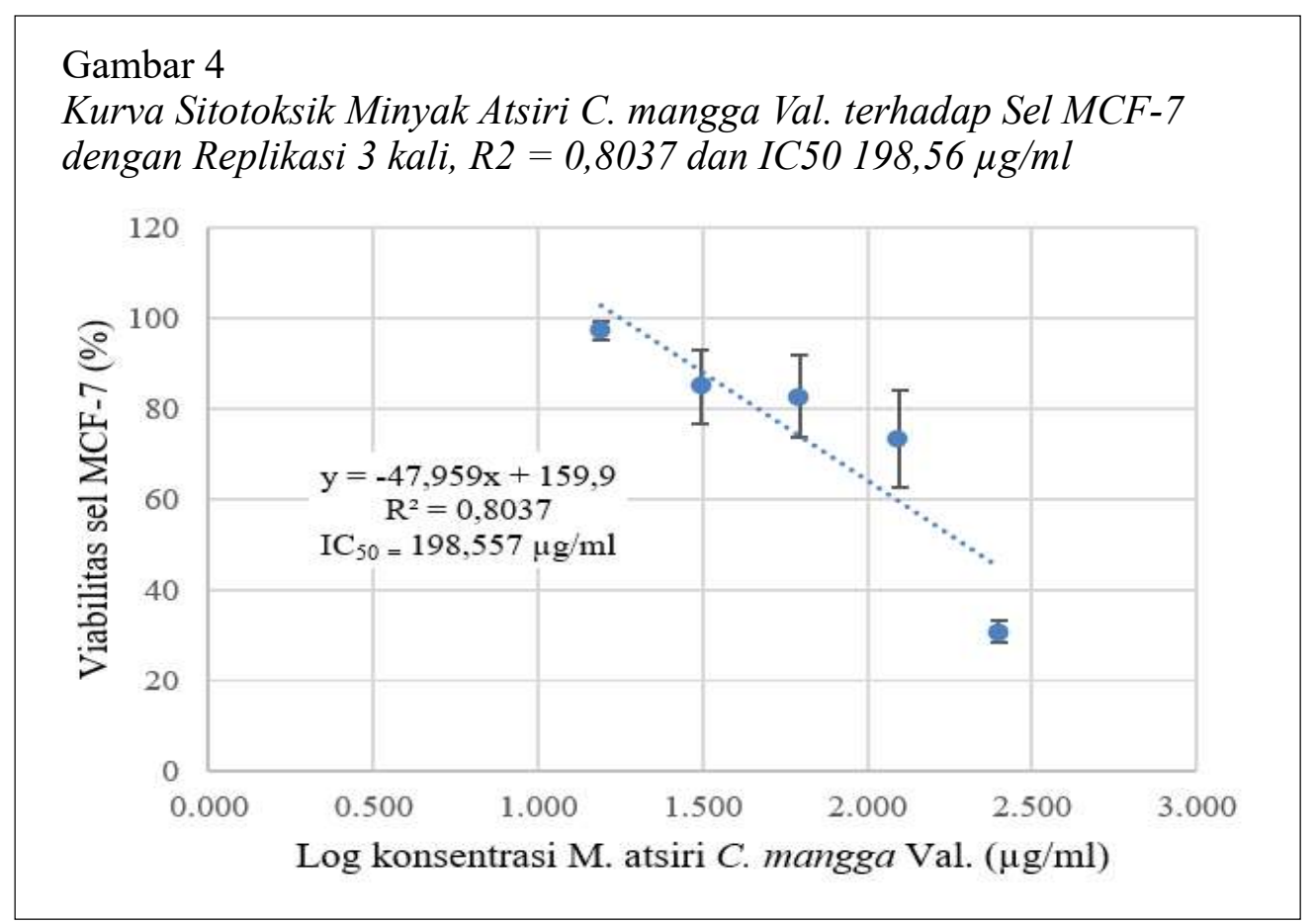

Hasil fraksinasi ekstrak $n$-heksana dan minyak atsiri rimpang C. mangga Val. terdapat pada Gambar 5 dan 6. Fraksinasi ekstrak $n$-heksana rimpang C. mangga Val. menghasilkan 38 puncak kandungan senyawa (Gambar 5); sedangkan fraksinasi minyak atsiri rimpang C. mangga Val. menghasilkan 41 puncak kandungan senyawa (Gambar

Gambar 5

Kromatogram Fraksinasi Ekstrak n-heksana Rimpang C. mangga Val.

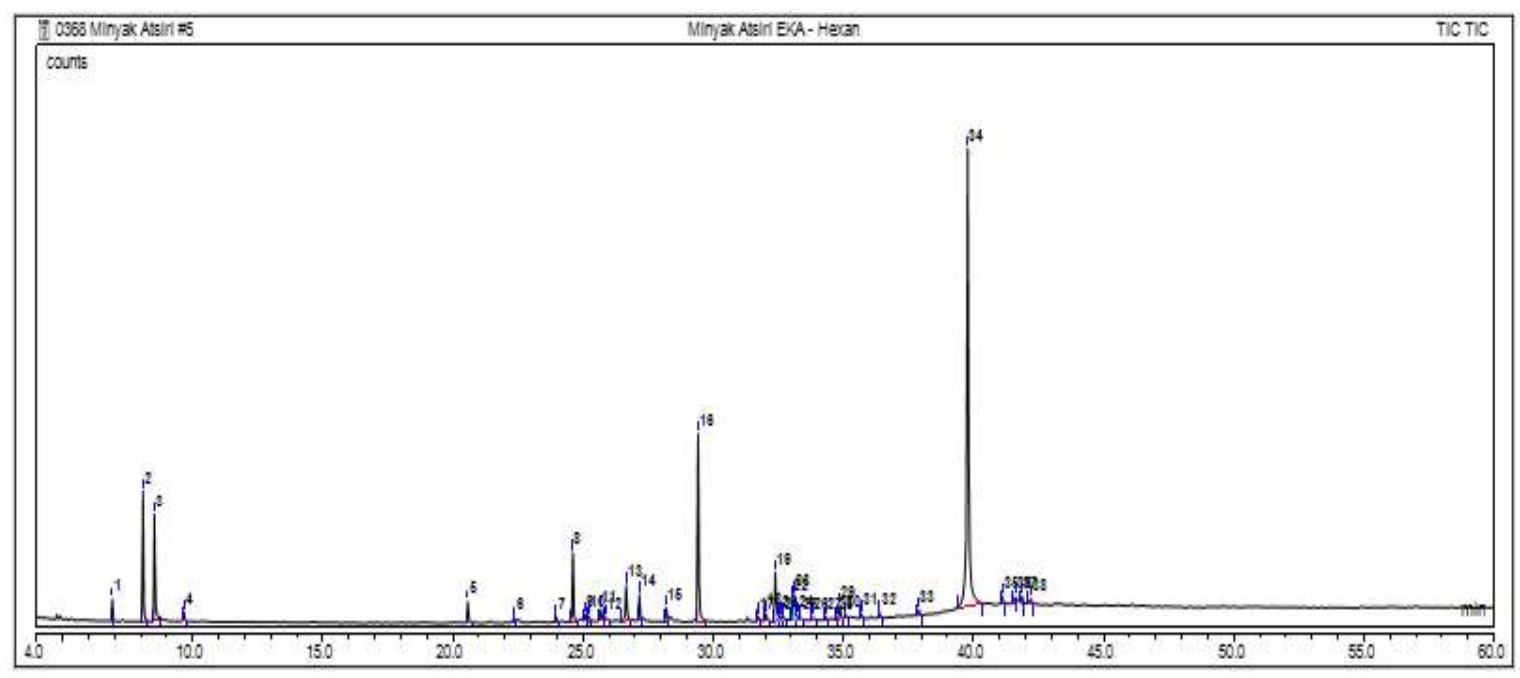


6). Hasil identifikasi dan seleksi kandungan senyawa dari ekstrak $n$-heksana dan minyak atsiri rimpang C. mangga Val. berdasarkan Similarity Index $(\mathrm{SI}) \geq 850$ dan Kelimpahan Relatif (Area relatif) $\geq 1 \%$ berturut-turut terdapat pada Tabel 2 dan 3.

Tabel 2 dan 3 menunjukkan bahwa kandungan minyak atsiri rimpang $C$. mangga Val. mayoritas adalah golongan monoterpenoid (51,34\%); sedangkan kandungan ekstrak $n$-heksan mayoritas adalah golongan diterpenoid $(53,18 \%)$. Sedangkan kandungan sesquiterpene untuk minyak atsiri dan ekstrak $n$-heksana rimpang C. mangga Val. hampir sama, yaitu berturutturut 14,06 dan $22 \%$.

Studi molecular docking terhadap reseptor ER $\alpha$ menunjukkan bahwa kandung- an senyawa minyak atsiri rimpang $C$. mangga Val. yang termasuk dalam golongan sesquiterpen memberikan docking score yang lebih baik dibandingkan senyawa yang masuk dalam golongan monoterpenoid (Khudzaifi, 2021). Kandungan golongan sesquiterpene dan juga diterpene lebih banyak terdapat pada ekstrak $n$-heksan daripada minyak atsiri, maka sejalan dengan uji sitotoksisitasnya, terbukti bahwa ekstrak $n$-heksan lebih sitotoksik dibanding minyak atsirinya.

Malek dkk. (2011) menjelaskan bahwa ekstrak $n$-heksana rimpang C. mangga Val. mengandung senyawa-senyawa yang tidak terdapat dalam minyak atsirinya, yaitu seperti (E)-Labda-8(17),12-diene-15,16dial yang merupakan senyawa diterpene

\section{Gambar 6}

Kromatogram Fraksinasi Minyak Atsiri Rimpang C. mangga Val.

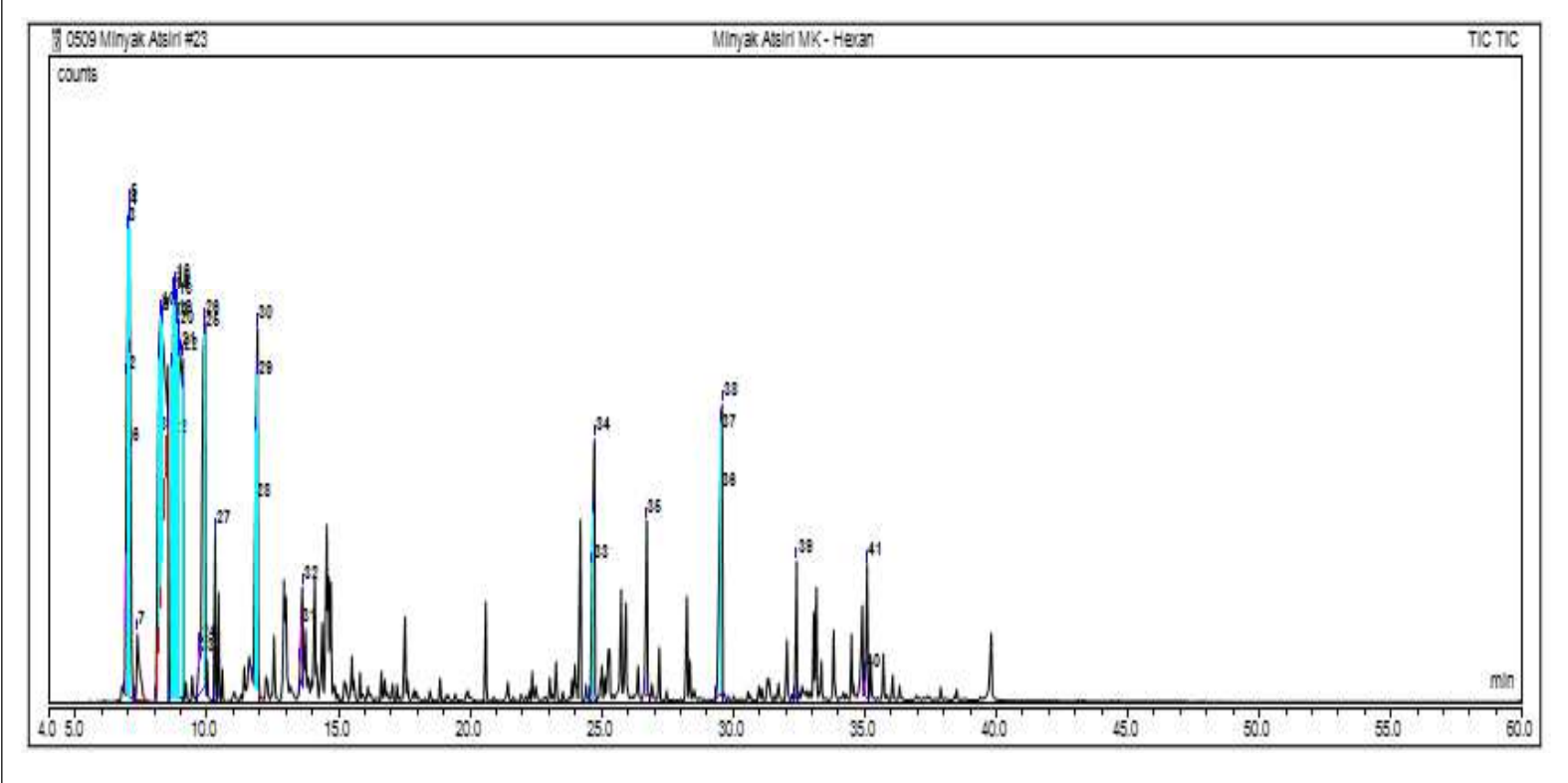


Tabel 2

Senyawa Kandungan Ekstrak n-heksana Rimpang C. mangga Val. dengan SI $\geq 850$ dan Kelimpahan Relatif (Area Relatif) $\geq 1 \%$

\begin{tabular}{|c|c|c|c|c|c|c|}
\hline No. & $\begin{array}{l}\text { Waktu } \\
\text { Retensi } \\
\text { (min) }\end{array}$ & Nama Senyawa & Struktur kimia & $\begin{array}{c}\text { Berat } \\
\text { Molekul }\end{array}$ & SI & $\begin{array}{c}\text { Area } \\
\text { Relatif } \\
(\%)\end{array}$ \\
\hline \multicolumn{7}{|c|}{ Monoterpenoid $=13.43 \%$} \\
\hline 1 & 6,91 & a-Pinene & & 136 & 873 & 0,93 \\
\hline 2 & 8,09 & $\beta$-Pinene & & 136 & 915 & 6,19 \\
\hline 3 & 8,53 & $\beta$-Myrcene & & 136 & 891 & 6,31 \\
\hline \multicolumn{7}{|c|}{ Sesquiterpenoid $=22 \%$} \\
\hline 4 & 20,57 & Caryophyllene & & 204 & 861 & 1,29 \\
\hline 5 & 24,60 & Caryophyllene oxide & & 220 & 907 & 4,37 \\
\hline 6 & 26,65 & $\begin{array}{l}\text { Alloaromadendrene } \\
\text { oxide-(1) }\end{array}$ & & 220 & 816 & 2,83 \\
\hline 7 & 27,16 & Germacrone & & 218 & 859 & 1,32 \\
\hline 8 & 29,42 & Ambrial & & 234 & 926 & 12,19 \\
\hline \multicolumn{7}{|c|}{ Diterpenoid $=53,18 \%$} \\
\hline 9 & 32,38 & m-Camphorene & & 272 & 904 & 3,91 \\
\hline
\end{tabular}


Perbandingan Aktivitas Sitotoksik (Cahyaningrum, P. K., Purwanto, \& Sudibyo, R. S.)

Lanjutan Tabel 2

\begin{tabular}{ccccccc}
\hline No. & $\begin{array}{c}\text { Waktu } \\
\text { Retensi } \\
(\mathrm{min})\end{array}$ & Nama Senyawa & Struktur kimia & $\begin{array}{c}\text { Berat } \\
\text { Molekul }\end{array}$ & $\begin{array}{c}\text { Area } \\
\text { Relatif } \\
(\%)\end{array}$ \\
\hline 10 & 33,05 & p-Camphorene & 272 & 840 & 1,26 \\
11 & 39,78 & $\begin{array}{c}\text { (E)-Labda-8(17),12- } \\
\text { diene-15,16-dial }\end{array}$ & 302 & 918 & 46,09
\end{tabular}

Non-terpenoid $=6,49 \%$

$12 \quad 33,24$ Ethyl iso-allocholate

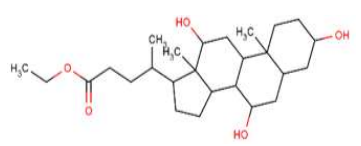

$436 \quad 725 \quad 4,99$

$13 \quad 32,03 \quad 1$-Heptatriacotanol

$\begin{array}{lll}536 & 732 & 1,50\end{array}$

Diterpenoid $=53,18 \%$

$1433,12 \begin{aligned} & \text { (E)-15,16-Dinorlabda- } \\ & \text { 8(17),11-dien-13-one }\end{aligned}$

Keterangan:* kelimpahan relatif kandungan berdasarkan golongan senyawa: Monoterpenoid $=13,43 \%$;

Sesquiterpenoid $=22 \%$; Diterpenoid $=53,18 \%$; Non-terpenoid $=6,49 \%$

Tabel 3

Senyawa Kandungan Minyak Atsiri Rimpang C, mangga Val, dengan SI $\geq 850$ dan

Kelimpahan Relatif (Area Relatif) $\geq 1 \%$ *

\begin{tabular}{|c|c|c|c|c|c|c|}
\hline No. & $\begin{array}{c}\text { Waktu } \\
\text { Retensi } \\
\text { (min) }\end{array}$ & Nama Senyawa & Formula Kimia & $\begin{array}{c}\text { Berat } \\
\text { Molekul }\end{array}$ & SI & $\begin{array}{c}\text { Area } \\
\text { Relatif } \\
(\%)\end{array}$ \\
\hline \multicolumn{7}{|c|}{ Monoterpenoid = 51,34\% } \\
\hline 1 & 7,09 & $\alpha$-Pinene & & 136 & 922 & 9,7 \\
\hline 2 & 7,02 & $\beta$-Thujene & & 136 & 906 & 5,43 \\
\hline 3 & 7,35 & Camphene & & 136 & 943 & 1,73 \\
\hline 4 & 8,14 & ß-Pinene & & 136 & 912 & 14,03 \\
\hline
\end{tabular}


Jurnal Penelitian Saintek, Volume 26, Nomor 1, 2021

Lanjutan Tabel 3

\begin{tabular}{|c|c|c|c|c|c|c|}
\hline No. & $\begin{array}{c}\text { Waktu } \\
\text { Retensi } \\
(\mathrm{min})\end{array}$ & Nama Senyawa & Struktur kimia & $\begin{array}{c}\text { Berat } \\
\text { Molekul }\end{array}$ & SI & $\begin{array}{c}\text { Area } \\
\text { Relatif } \\
(\%)\end{array}$ \\
\hline 5 & 8,66 & B-Myrcene & & 136 & 912 & 14,03 \\
\hline 6 & 9,90 & Eucalyptol & & 154 & 913 & 9.97 \\
\hline 7 & 10,31 & ß-Ocimene & & 136 & 932 & 1.50 \\
\hline 8 & 11,83 & Perillene & & 150 & 871 & 4.36 \\
\hline 9 & 11,92 & $\begin{array}{l}\text { Cyclohexane, 2-ethenyl- } \\
\text { 1,1-dimethyl-3- } \\
\text { methylene- }\end{array}$ & & 150 & 782 & 3.32 \\
\hline 10 & 13,62 & Pinocarvone & & 150 & 806 & 1.30 \\
\hline \multicolumn{7}{|c|}{ Sesquiterpenoid $=14,06 \%$} \\
\hline 11 & 24,64 & Caryophyllene oxide & & 220 & 915 & 4.89 \\
\hline 12 & 26,71 & $\begin{array}{l}\text { Aromadendrene } \\
\text { oxide-(2) }\end{array}$ & & 220 & 851 & 2.31 \\
\hline 13 & 29,50 & Ambrial & & 234 & 900 & 6.86 \\
\hline \multicolumn{7}{|c|}{ Diterpenoid $=2,82 \%$} \\
\hline 14 & 32,41 & m-Camphorene & & 272 & 926 & 1.30 \\
\hline 15 & 35,09 & Geranyllinalool & & 290 & 715 & 1.52 \\
\hline
\end{tabular}

Keterangan: * kelimpahan relatif kandungan berdasarkan golongan senyawa: Monoterpenoid $=51,34 \%$; Sesquiterpenoid $=14,06 \%$; Diterpenoid $=2,82 \%$ 
yang memiliki potensi sitotoksik terhadap sel MCF-7. Sedangkan minyak atsiri rimpang C. mangga Val. mengandung senyawa monoterpene dan sesquiterpene yang mudah menguap; tidak mengandung senyawa diterpene (Astuti dkk., 2014a; Sudibyo, 2000). Hasil penelitian ini dapat digunakan sebagai dasar pelaksaaan ekstraksi kandungan rimpang C. mangga Val. dalam pengembangannya sebagai obat herbal terstandar atau fitofarmaka.

\section{SIMPULAN}

Rendemen minyak dari ekstrak $n$-heksana rimpang $C$. mangga Val. adalah $1,15 \times 10^{-2} \%$ sedangkan rendemen minyak atsiri adalah $6,3 \times 10^{-2} \%$. Aktivitas sitotoksik minyak dari ekstrak $n$-heksana rimpang C. mangga Val. lebih kuat daripada isolat minyak atsirinya karena $\mathrm{IC}_{50}$ minyak dari ekstrak $n$-heksana $=106,414 \mu \mathrm{g} /$ $\mathrm{ml}$ lebih kecil dibandingkan dengan $\mathrm{IC}_{50}$ minyak atsiri $=198,557 \mu \mathrm{g} / \mathrm{ml}$. Meskipun demikian, potensi sitotoksik keduanya (ekstrak $n$-heksana dan minyak atsiri) masih termasuk dalam golongan cukup kuat.

\section{DAFTAR PUSTAKA}

Astuti, E. (2015). Selektivitas dan mekanisme molekuler antikanker ekstrak aktif rimpang curcuma mangga Val (Disertasi tidak diterbitkan). Universitas Gadjah Mada, Yogyakarta.

Astuti, E., Sunarminingsih, R., Jenie, U.A., \& Mubarika, S. (2014a). Pengaruh lokasi tumbuh, umur tanaman dan variasi jenis destilasi terhadap komposisi senyawa minyak atsiri rimpang curcuma mangga produksi beberapa sentra di Yogyakarta. J. Manusiadan Lingkungan, 21(3), 323330.

Astuti, E., Sunarminingsih, R., Jenie, U.A., Mubarika, S., \& Sismindari, S. (2014b). Impact of Curcuma mangga Val. rhizome essential oil to p53, Bcl2, H-Ras and Caspase-9 expression of myeloma cell line. Indonesian Journal of Biotechnology, 19, 23-32.

Boyd, M. R. (2004). The NCI in vitro anticancer drug discovery screnn, anticancer drug development guide dalam preclinical screening, clinical trials, and approval. Humana Press Inc.

Khudzaifi, M. (2021). Isolasi dan karakterisasi minyak atisiri curcuma mangga val. serta identifikasi dan studi molecular docking senyawa aktif antikanker payudara (Tesis tidak diterbitkan). Universitas Gadjah Mada, Yogyakarta, Indonesia.

Malek, S. N. A., Lee, G. S., Hong, S. L., Yaacob, H., Wahab, N. A., Faizal Weber, J. F., \& Shah, S. A. A. (2011). Phytochemical and cytotoxic investigations of Curcuma mangga rhizomes. Molecules, 16(6), 4539-4548.

Sudibyo, R. S. (2000). Gaschromatographicmass spectrometric analysis of the main content of volatile oil isolated from Curcuma mangga. BMIPA, 10, 55-6.

Sudibyo, R. S., \& Taryono. (2020). Pemupukan dan induksi curcuma mangga Val. untuk peningkatan zat antikanker dan uji sitotoksitasnya pada T47D. Jurnal Penelitian Saintek, 25(1), 1-10. Verlianara, I. (2004). Efek in vitro minyak atsiri Curcuma mangga Val pada 
sitotoksisitas, antiproliferatif dan apoptosis sel raji dan mieloma (Tesis tidak diterbitkan). Universitas Gadjah Mada, Yogyakarta.

Wahyuningsih, M. S. H., Mubarika, S., Bolhuis, R. L. H., Nooter, K., \& Oostrum, R. G. (2003). Sitotoksisitas rimpang temu mangga (Curcuma mangga val. \& V. zijp.) dan kunir putih (Curcuma zedoria i.) terhadap beberapa sel kanker manusia (in vitro) dengan metoda SRB. Journal of the Medical Sciences (Berkala Ilmu Kedokteran), 35(4). 